\title{
Zes stemmen voor de mannen
}

Citation for published version (APA):

Fouarge, D. (2008). Zes stemmen voor de mannen. Tijdschrift voor Arbeidsvraagstukken, 24(2), 111-113.

Document status and date:

Published: 01/01/2008

Document Version:

Publisher's PDF, also known as Version of record

\section{Please check the document version of this publication:}

- A submitted manuscript is the version of the article upon submission and before peer-review. There can be important differences between the submitted version and the official published version of record.

People interested in the research are advised to contact the author for the final version of the publication, or visit the DOI to the publisher's website.

- The final author version and the galley proof are versions of the publication after peer review.

- The final published version features the final layout of the paper including the volume, issue and page numbers.

Link to publication

\footnotetext{
General rights rights.

- You may freely distribute the URL identifying the publication in the public portal. please follow below link for the End User Agreement:

www.umlib.nl/taverne-license

Take down policy

If you believe that this document breaches copyright please contact us at:

repository@maastrichtuniversity.nl

providing details and we will investigate your claim.
}

Copyright and moral rights for the publications made accessible in the public portal are retained by the authors and/or other copyright owners and it is a condition of accessing publications that users recognise and abide by the legal requirements associated with these

- Users may download and print one copy of any publication from the public portal for the purpose of private study or research.

- You may not further distribute the material or use it for any profit-making activity or commercial gain

If the publication is distributed under the terms of Article $25 \mathrm{fa}$ of the Dutch Copyright Act, indicated by the "Taverne" license above, 


\section{Zes stemmen voor de mannen}

\section{Didier Fouarge*}

Nederland is bezorgd over het te lage aantal uren dat door vrouwen wordt gewerkt. Wat is er precies aan de hand? Volgens cijfers van het CBS stijgt de arbeidsparticipatie van vrouwen - en dan vooral van moeders met jonge kinderen - onophoudelijk sinds 1985, terwijl het aantal gewerkte uren daalt. Gemiddeld genomen is de jaarlijkse arbeidsduur van vrouwen ongeveer $30 \%$ lager dan die van mannen. Het aandeel vrouwen in voltijdbanen is laag en vertoont door de tijd heen geen spoor van verandering. Volgens politiek Den Haag is dit een probleem. Om die reden besloten kabinet, werkgeversen werknemersvertegenwoordigers een Taskforce DeeltijdPlus in het leven te roepen, met als hoofddoel het bevorderen dat vrouwen meer uren gaan werken. De installatie van de Taskforce op 8 april jl. ging gepaard met een symposium met presentaties en debat rond het thema 'Deeltijdwerk in Nederland'. Het symposium werd goed bezocht door vertegenwoordigers van verschillende ministeries, de planbureaus $C P B$ en SCP, het maatschappelijk middenveld en wetenschappers.

Aan de hand van een drietal stellingen werd gepeild hoe de aanwezigen (25 mannen en 65 vrouwen volgens de deelnemerslijst) dachten dat het aantal gewerkte uren van vrouwen het beste omhoog te krijgen is. De drie stellingen die ter stemming werden voorgelegd, waren: het aantal gewerkte uren van vrouwen kan het beste verhoogd worden door (1) in te zetten op de rol van de man, (2) in te zetten op een cultuurverandering van werkgevers, of (3) in te zetten op de arbeidsparticipatie van vrouwen zonder jonge kinderen. Enige toelichting is op zijn plaats.

Stelling 1 (zeg maar 'de man') kan gemotiveerd worden vanuit de gedachte dat de man mede verantwoordelijk is voor het feit dat zijn vrouwelijke partner onvoldoende uren werkt. Mannen zouden te inflexibel zijn en niet bereid zijn hun eigen arbeidsaanbod aan te passen op momenten waarop dit wel goed van pas zou komen (bijv. als de kinderen nog klein zijn). De telling van de stemmen voor deze stelling was snel klaar: zes stemmen voor 'de man'! Dit is merkwaardig weinig als je bedenkt dat het aantal gewerkte uren van mannen inderdaad ongevoelig is voor belangrijke levensgebeurtenissen als de geboorte van kinderen en dat de economische literatuur heeft gewezen op het feit dat het arbeidsaanbod van paren feitelijk als een gemeenschappelijke beslissing kan worden gezien, waaraan onderhandeling te pas komt. Dat de stelling zo weinig steun kreeg, is te begrijpen vanuit de atypische samenstelling van de deelnemers aan het symposium: hoofdzakelijk hoogopgeleide vrouwen met bovengemiddeld ambitieniveau die thuis hun mannetje staan.

De motivatie voor stelling 2 (zeg maar 'de werkgever') is dat werkgevers onvoldoende ruimte zouden geven aan vrouwen om hun arbeidsduur flexibel in te richten. Beginen eindtijd van je werkdag zou je vaker zelf moeten bepalen en er zouden meer mogelijkheden moeten komen voor thuiswerken, zo luidt de stelling. De klacht is ook dat vrouwen die tijdelijk hun loopbaan hebben onderbroken of tijdelijk minder zijn gaan werken, minder gemakkelijk in aanmerking komen voor een functie in voltijd die vergelijkbaar is met de oude functie. Ongeveer de helft van de aanwezigen kon zich daar wel in vinden. Werkgevers hebben een belangrijke bijdrage geleverd aan de opkomst

* Didier Fouarge is lid van de redactie van het Tijdschrift voor Arbeidsvraagstukken. 
van de Nederlandse vrouw op de arbeidsmarkt. Door in de jaren negentig massaal deeltijdwerk mogelijk te maken hebben zij veel vrouwen naar de arbeidsmarkt weten te lokken. Dat is winst. Maar hun inflexibele houding nu wordt hen kennelijk zwaar aangerekend. Een bijkomend punt is dat werkgevers weinig investeren in hun parttimers en dat de uitgaven van bedrijven aan zaken die de combinatie van arbeid en zorg beter mogelijk moeten maken, betrekkelijk laag zijn.

De derde stelling (zeg maar 'de vrouw zonder zorgtaken') kon eveneens rekenen op van de steun van ongeveer de helft van de aanwezigen. Waar het om gaat, is het volgende: de arbeidsparticipatie van jonge vrouwen (in personen en in uren) is hoog, maar daalt rond de geboorte van het eerste kind. De participatie in personen herstelt zich deels in de paar jaren na de geboorte, maar het aantal gewerkte uren niet. Dit komt doordat steeds meer vrouwen die geen jonge kinderen meer hebben er de voorkeur aan geven om in deeltijd te blijven werken. De gedachte is dat er een substantieel arbeidspotentieel te halen is in deze groep van vrouwen die geen zorgtaken (meer) hebben.

Dat vrouwen die na de geboorte van een kind blijven werken dat veelal in deeltijd blijven doen - ook als de kinderen ouder worden - is een typisch Nederlands verschijnsel. Maar het is beslist geen nieuw verschijnsel. Onderzoek op basis van retrospectieve data heeft laten zien dat Nederlandse vrouwen uit eerdere geboortecohorten dit ook al deden. ${ }^{1}$ Het enige verschil is dat de Nederlandse moeder van nu zich minder snel terugtrekt uit de sfeer van betaalde arbeid dan moeders die aan het begin van de twintigste eeuw geboren zijn. Het aantal gewerkte uren van moeders uit andere landen (uit oude of recente geboortecohorten) neemt wel toe naarmate de kinderen ouder worden.

Het lijkt er dus op dat de Nederlandse vrouw een diepgewortelde voorkeur heeft voor werken in deeltijd en dat deze voorkeur niet enkel is ingegeven door de instituties, maar een verder liggende historische oorzaak heeft. Het feit dat zoveel vrouwen zonder zorgtaken in deeltijd werken, ondersteunt deze stelling. Deze voorkeur voor deeltijd is op zichzelf niet erg, want de rest van de werkweek kan dan aangewend worden voor vrijetijdsbesteding, huishoudproductie of andere maatschappelijk nuttige activiteiten die vanuit economisch oogpunt ook meerwaarde hebben. Voor de vrouwen die wel een voorkeur koesteren voor een voltijdbaan is het belangrijk dat de institutionele context dusdanig is ontwikkeld dat hun wens kan worden vervuld. Ten eerste hebben zij daar wel degelijk de medewerking van hun man bij nodig. Ten tweede moeten er institutionele faciliteiten aanwezig zijn die het combineren van arbeid en zorg mogelijk maken. De huidige discussie rond de bekostiging van de kinderopvang laat zien dat dit niet vanzelfsprekend is. In het geval van vrouwen zonder zorgtaken is dit natuurlijk niet afdoende. Hun lage arbeidsaanbodelasticiteit houdt in dat er krachtige prikkels noodzakelijk zijn om hen te bewegen meer uren te gaan werken. Ten derde moeten de werkgevers inderdaad ook meewerken. Wat dit betreft is het, denk ik, slechts een kwestie van tijd: werkgevers zullen gauw genoeg begrijpen dat uit concurrentieoverwegingen het onbenut laten van vrouwelijk talent hen duur kan komen te staan. Ten slotte zou het goed zijn om zich af te vragen in welke mate het feit dat vrouwen gedurende hun loopbaan hun aantal gewerkte uren niet naar boven herzien, wellicht te maken heeft met een aversie voor verandering: bij een aanpassing van de arbeidsduur dienen andere gemaakte afspraken opnieuw te worden bezien. Misschien is dit de reden dat Nederlandse vrouwen meer moeite hebben met het aanpassen van hun arbeidsduur. 
In ieder geval lijkt er werk aan de winkel te zijn voor de Taskforce. Zeker als je bedenkt dat zijn mandaat slechts is beperkt tot twee jaar.

\section{Noot}

1 Manzoni, A., Fouarge, D., Luijkx, R. \& Muffels, R. (2008). 'Childbirth and mother's labour supply: comparative evidence from life-history data for Germany, The Netherlands and Great Britain'. Ongepubliceerd manuscript. 